\title{
Contemporary Education - Changes of the System, Research Reports and the Dimensions of Real Social Expectations
}

\author{
Inetta Nowosad - Ewa Karmolińska-Jagodzik*
}

\begin{abstract}
The article attempts to analyze transitions which have occurred in education system in Poland during last years. The authors reveal numerous changes of the system on the basis of various reports, research results, public speeches and legal acts which have been put into practice. These changes are shown from teachers', pupils' and parents' point of view, and are corrected through the prism of social expectations. Moreover, the dilemmas of contemporary teacher are revealed, as well as expectations of the society which participates in constantly transforming reality of global world.
\end{abstract}

Key words: system of education, contemporary education, teachers, social expectation.

\section{Introduction}

Many changes have appeared in the field of teacher training. These transformations result from social expectations towards teachers' role as well as from the changing reality in which contemporary people participate. On one hand, the number of changes brings chances for everyone preparing for a professional role, but, on the other hand, it is an opportunity for creating such a reality when the implemented changes bring only superficial effects for a small group of people.

The education system in Poland has undergone a number of changes resulting from transformation of the political system and expanding knowledge in the field of children and youth upbringing psychology.

Changes in the balance of power prevailing in families and the image of contemporary families, transition from post-figurative to pre-figurative culture, or individual expectations towards consumer system of values have brought the need of change inside education systems which arise from the growing requirements towards teachers. Changes introduced in Poland were assessed in a positive way and Poland indeed is heading in PISA 2012 (http://www.ibe.edu.pl/pl/o-instytucie/aktualnosci/293-pisa-2012-wyniki,

\footnotetext{
* Inetta Nowosad, University of Zielona Góra, Zielona Góra, Poland; inettanowosad@wp.pl Ewa Karmolińska-Jagodzik, Adam Mickiewicz University in Poznań, Poznań, Poland; ekarmolinska@wp.pl
} 
viewed on 23 June 2014) and Talis 2013 (http://eduentuzjasci.pl/badania/110badanie/599-talis-miedzynarodowe-badanie-nauczania-i-uczenia-sie-2.html, viewed on 23 June 2014) report as it comes to education.

\section{Discussion}

In 2010, when the European Higher Education Area - EHEA office was officially established, essential structural, curricular and organisational changes appeared in education systems of the countries which had signed the Bologna Declaration in 1999 (Bologna Declaration, 2004). The area of international cooperation was reinforced, which is apparent, be it only, in the significant increase in the number of countries assimilating the Bologna declarations.

Nonetheless, the process of the introduction of changes was characterised by a certain kind of dynamics in particular countries (despite of comparable framework of general performance conditions), in which the attachment to native traditions remained in lasting conflict in policies stipulated by the European Union. Drawing up temporary balance of the transformations instigated in the practice of Poland's higher education, we may surmise that the process aroused the most of controversies in the area of teacher training and further development.

Such a circumstance has its roots in multiple phenomena, such as correlation of resolutions of the Bologna Declaration with the postulates related to the preparation of teachers to work in the reform system*. Poland-specific demographic phenomena and the requirements of the labour market played an equally consequential role, leading to the final acceptance of one type of solutions over another. For deeper insight into the state and manner of teacher training in Poland and into the country-specific dilemmas, we need to be able to perceive a broader context of the undergoing transformations, such as general alterations being instigated within Poland's higher education or the status quo and the levels of practical implementation of the Bologna Process in Poland's academic institutions.

It seems to be essential to pay attention to the expectations towards teachers resulting from micro-social context, i.e. from people who are most interested in introducing changes in the field of teacher's professional training - pupils' parents. Despite the fact, that these groups are the least aware of the changes

\footnotetext{
* The reform of the education system was introduced in 1999. The main objectives delineating the direction of changes were as follows: popularisation of secondary and higher education, provision of equal chances in the access to education and integral incorporation of skills training and acquisition of knowledge into education. The adopted attitude entailed the undertaking of simultaneous efforts meant, on the one hand, to prepare the already employed teachers to the implementation of new objectives instituted in the wake of the reforms, and on the other hand, to prepare new teaching personnel.
} 
which are being made in the area of teachers' higher education, they have their specific expectations towards the awaited shape of the teacher training system.

\section{The structure of teacher training}

In Poland, teachers constitute the most numerous business functions. Since the 1970s, they have been required to complete higher education and undergo constant self-improvement (cf. Zawadowski). Teacher training for different types of schools is instituted by means of double-track procedures: within the system of higher education and within the system of general education. The newest legal act concerning teacher training at higher schooling institutions is the 2005 decree Higher education law, and there is the 7 September 1991 decree on education system with relation to teacher training colleges*.

Within the system of higher education, teacher training is conducted at institutions which are authorised with the right to award the best of their graduates with a PhD. degree, such as universities, polytechnics and academies, but also vocational higher schooling institutions which are not authorised to award the $\mathrm{PhD}$. degree to their graduates (Organizacja system edukacji, 2009). The following types of studies prepare for the teaching profession:

- undergraduate studies (BA or engineering),

- graduate studies (MA),

- uniform MA studies,

- post-graduate studies.

The recruitment to teacher training faculties fails to take into consideration the superimposed recruitment quota. Particular institutions are autonomous in this respect and the educational policies of the state are applicable through the stipulation of qualification requirements to undertake teacher training, as well as the introduction of minima curricula.

Teacher training at higher schooling institutions is predominantly executed on faculties preparing specialists for a particular profession, e.g. the faculties of Chemistry prepares specialists to work in factories, research-scientific institutions, but also teachers of Chemistry; accordingly, the faculties of Classical Philology prepare specialists to work at publishing houses, at research institutions, but also teachers of Latin and Greek.

Students may select the teachers' profile within many faculties and, consequently, acquire pedagogical preparation in the course of their studies, or complete a given course without a specialisation and supplement the teacher qualification at postgraduate studies or qualification courses. Higher schools had previously trained teachers in merely one specialisation, but in recent years,

\footnotetext{
* The detailed principles concerning the functioning of colleges are stipulated by the 12 August 1997 resolution of the Minister of National Education concerning teacher training institutions, which has the status of an executable law to the Act of Education System.
} 
according to the binding standards of teacher training, studies of two specialties have been introduced (two-course studies), which, similarly to other countries of the European Union, merge kindred specialties, such as: Mathematics and Chemistry, History and Social Studies, English and German, etc.

Curricula and courses of studies at higher educational institutions are autonomously stipulated by the authorities of particular institutions. The General Council for Higher Education, which is an establishment superior to all higher education institutions in Poland, stipulates minimal curricular requirements for particular faculties, as well as minimal time load for particular subjects. A minimum load for the undergraduate studies is 2200 hours, and for graduate 5year studies the figure is 3000 . However, in principle, teacher training is not limited to minima and typically encompasses from 2300 to 2500 hours for undergraduate studies, depending on the faculty, and from 3300 to 3500 for five-year graduate studies. The scope of qualifications and the minimal number of hours for pedagogical preparation are stipulated by the Minister of National Education. According to ministerial regulations, pedagogical preparation must encompass the following:

- $\quad$ in the 3-year cycle for a single specialty: 510 hours (330 of theory and 180 of practice);

- in the 5-year cycle for a single specialty: 480 hours (330 of theory and 150 of practice);

- in the 5-year cycle for two specialties: 600 hours (390 of theory and 210 of practice);

At colleges preparing future teachers for teaching two subjects, there are the following instruction standards in force: requirements related to curricula, types of subjects, the form and extent of pedagogical practice, curricular content and required skills. Instruction at teachers' colleges is executed for specialties that have their equivalents in subjects taught at schools. Similarly to higher education institutions, the Minister of National Education stipulates the qualifications required from teachers, as well as the minimum number of hours allotted to pedagogical preparation at teacher training colleges, which are:

- at 3-year teacher training colleges preparing in two specialties, there are 540 hours of pedagogical preparation in force (360 of theory and 180 of practice);

- at 3-year language teachers' colleges there 510 hour of pedagogical instruction (360 of theory and 150 of practice).

The profile of a graduate has been stipulated in the recent regulations in the form of the following competencies:

- preparation in the selected specialties,

- preparation in psychology and pedagogy,

- practice in the didactics of the selected subject,

- computer skills,

- command in at least one foreign language at B2 level, 
- cooperation skills in relation to pupils, teachers, pupils' family members and the external community in terms of execution of common educational objectives,

- skills of undertaking educational tasks surpassing the taught subject,

- skills of designing own activity and undertaking initiatives desirable for pedagogical practice.

Those who have higher education with appropriate pedagogical preparation or have graduated from a teachers' college may commence teaching at a selected institution on the territory of the whole country as fully qualified teachers. The final on-the-job qualifying phase, which involves attaining formal qualifications in the workplace, is not present in the Polish system. Novice teachers are employed for one year as interns in order to be promoted to the status of contract teachers. Accordingly, teachers -interns may not be placed in the category of people supplementing their qualifications, but are rather placed at the lowest rank in the hierarchy of professional advancement*. Teachers are employed by head teachers by means of open recruitment procedures.

At the beginning of 2012, the Minister of Education, Krystyna Szumilas, signed the decree on educational standards for the teaching profession, submitted by the Minister of Science and Higher Education. The decree was signed on the 17th of January 2012, according to authorisation in the art. $9 \mathrm{c}$ of the act from the 27th of July 2005 Law on Higher Education (Dz. U No. 164, pos. 1365, as amended). Due to the law, the minister competent for higher education was obliged to issue an agreement with the minister competent for educational and pedagogical matters to specify standards of training for the teaching profession.

Regulations of the decree specify:

1. effects of education in the scope of

- content-related and methodological knowledge,

- pedagogical and psychological knowledge, including pedagogical matters as well, taking into consideration teachers' preparation for working with pupils with special educational needs,

- training to apply information technology,

- foreign language level

2. duration of studies and postgraduate studies,

3. dimensions and organization of practices.

According to the new standards, on the basis of the last amendment to Law on Higher Education, two-specialty education, compulsory so far on undergraduate studies, was rejected. Professional teacher training is based on modules and its

\footnotetext{
* According to the Teacher's Charter amended in 2000, Polish teachers may attain the following stages of professional advancement: junior teacher, contract teacher, appointed teacher and certified teacher. Also, it is possible to award some distinguished certified teachers with the honour title of professor of education.
} 
realization will be possible during undergraduate, graduate and postgraduate studies.

Nursery school teachers and I-III grade primary school teachers will be trained in both scopes simultaneously.

Teachers' professional training will be conducted in three obligatory modules including subject teaching training (conducting classes), psychological and pedagogical training, and didactical training. It would be broaden with optional modules such as training to teach another subject (conducting classes) or training in the scope of special needs education.

Above all, teacher training should be focused on gaining practical skills crucial in the teaching profession. Theoretical knowledge is about to support the process of gaining these skills and to give a scientific synthesis of the gained experience. Therefore, regulations of the decree increased the role of practical training, particularly in the field of childcare education competence and diagnosing student's individual needs.

An important change is also the requirement that future teachers preparing for working in I-III grades of primary school, should demonstrate substantive skills in Polish language (creating texts), Mathematics (conducting mathematical reasoning) and Nature (illustrating natural phenomena by means of experiments). Gaining these competencies is obligatory to undertake didactic training, to realise pre-school core curriculum and general educational curriculum.

\section{Dilemmas concerning teacher training}

In the wake of dramatic systemic transformation, and also as a result of consistent introduction of the Bologna process, teacher training in Poland has faced a certain numbers of key dilemmas.

As we know, in the name of the education law contemporarily in force in Poland, future teachers may attain the required professional qualifications at various types of institutions, such as universities, polytechnics, pedagogical academies, academies of economy, physical education academies, academies of agriculture, higher vocational schools, and last but not the least, teachers' training colleges.

Teacher training at various types of institutions, naturally, has its advantages and disadvantages. A self-explanatory advantage is that teachers walk out with two professions, which enhances their chances for finding appropriate employment in the labour market; one disadvantage would be the comparatively low quality of instruction and no direct link with the changeable requirements of the labour market.

Poland's universities (17 institutions) comprise 400 teacher-training units provide paid and free of charge, undergraduate and graduate, full-time and external study programmes. And together with other state, and especially non- 
state higher teacher-training schools, it should not come as a surprise that there is an enormous "overproduction of teachers". Thus, educational authorities and researchers (including Bologna experts) continually emphasise that the recruitment of candidates for a profession should calculate the market's demand, as well as demographic predictions, according to which the quota for employing new teachers has already been exhausted until the year 2015 (Kształcenie nauczycieli przez wyższe uczelnie, 2006).

Accordingly, there is a disturbing phenomenon present in the Polish educational market, where graduates of teacher-training institutions have scant chances for employment in their area of expertise and consequently commence employment randomly, typically in the area of broadly understood service industry.

The majority of experts and head teachers maintain that the concentration of teacher training at universities is decidedly favourable, as they provide relatively higher quality levels. However, the scope of institutions entitled to teacher training is highly dependent on their decision of adopting particular recruitment and selection procedures. In Poland, unlike in Germany, where selected faculties are governed by the principle of numerous clauses, there exist no forms of central limitation of access to any type of instruction at the higher level of education. In this respect, higher education institutions are autonomous, and the educational policy of the state is implemented by mere stipulation of qualification requirements for the teaching profession, as well as by the introduction of curricular minima for teacher training studies.

Free access to higher education institutions is undoubtedly beneficial to all those who wish to be educated at later stages of their lives. For obvious reasons (personnel, finances, organisation, logistics) many institutions, especially the state-owned ones, introduce the selection of candidates. Thus, highly differentiated forms of preliminary recruitment are stipulated by particular institutions. As a consequence, future teachers are recruited on the basis of highly differentiated criteria, frequently, especially in cases of private institutions, with no preliminary requirements at all (apart from the secondary school leaving examination certificate), which is dangerous as such, and perilously deepens the extent of negative selection of the teaching profession (Wiłkomirska, 2004, pp. 3-4).

There is an urgent need for the redefinition of the profile and the role of teachers in the society of knowledge and in the conditions of lifelong education. In other words, to create a new balance of teachers' competences in the "Europe of Knowledge", i.e. a broadly advertised idea among the leaders of the European Union. Some endeavours, meant to lead us in this direction, have already been undertaken together with the initiatives towards standardisation of teacher training. It is of utmost importance that teachers who graduate from higher education institutions are optimally prepared for their didactic/pedagogical work in the school of the $21^{\text {st }}$ century. They must also become "teachers who are ready 
to be subjected to life-long education", as the knowledge acquired at the university is characterised by the ever-shrinking range of duration.

Life-long learning constitutes a basic element in the European Space of Higher Education. Teachers must attain the skills of continual self-improvement during the whole span of their professional career, with special attention paid to up-todate orientation in the dynamic development of new technologies. The precondition must be acknowledged, accepted beforehand and in consequence, relevant measures must be taken to undertake appropriate forms of selfimprovement and participation in the process of professional development (Furmańska, 2005, pp. 14-17).

Moreover, should teachers only want to upgrade their qualifications with the sole aim of their professional advancement, they will fail to attain satisfactory results; graduation from yet another postgraduate faculty has ceased to add to competiveness in the labour market, as creative and leadership skills are playing an ever-growing role. Among the proposals of the improvement of the existing teacher training curricula, there is a more and more dominant opinion that evaluation of these curricula should be processed at target schools, i.e. where teachers find their employment (cf. Rękawek, p. 8).

Another dilemma is reflected in the diversity of the teacher training system. The differences are accounted for by the fact that teachers are educated at state and non-state, academic and non-academic institutions, which on top of that feature an assortment of curricula, both in the content of particular subjects, and in the scope of pedagogical instruction (Kucharska, 2005, p. 208). Furthermore, teacher training is instituted separately on particular faculties, which may be conducive to marginalisation of the teacher's specialty and as such, may constitute a sizeable hindrance in the creation of a holistic vision of teacher training, regardless of their content-related preparedness.

Consequently, an illusory conviction is being disseminated that teachers teaching particular subjects, should have a different type of preparation for their professional functions. In our opinion, this conviction is fundamentally erroneous. It is true that teachers teaching different subjects should have different content-related preparation, and to a certain extent, different methodological training, but the essence of the teaching profession in each and every case remains unchanged. Thus, more and more frequently, there emerge proposals of some fundament organisational changes, such as: the creation of an inter-departmental unit or institute at all higher education institutions, which would deal solely with teacher training and which would integrate all applicable research-didactic efforts. The introduction of such a solution would be a milestone in the development of pedeutological practice and theory (Rękawek, p. 9).

The creation of an effective national system of teachers' professional development requires a deep reflection. Thus, teachers' professional development instigated by higher education institutions should not only take into 
consideration the demand of the labour market and employment possibilities, but also be compatible with the requirements posed to teaching-specialty graduates by work in the reformed school (Rękawek, p. 9). Teachers should be equipped with appropriate methodological/practical competence in the process of their training, which is based on knowledge related to developmental and cognitive psychology. The main objective of higher education is preparation of future teachers for making independent decisions and searching solutions to socialeducational problems (Włoch, 2005, pp. 221-227). Pedeutological research in this area unequivocally proves that teachers are insufficiently prepared for their pedagogical profession (Wiłkomirska, 2005).

An additional quandary results from high tuition fees for postgraduate studies; costs that teachers frequently have to reimburse from their family budgets, which are based on remuneration far below the national average.

The hitherto research related to the teaching profession confirms the perseverance of a certain paradox over many years now. Thus, on the one hand, civilizational and cultural changes, with the dynamic development of new technologies to boot, require from teachers the attainment of new and increasingly expanded competencies in many areas. On the other hand, there has been a steady decrease in the teachers' social prestige, let alone such negative phenomena as negative selection to the profession, relatively low remuneration, record-breaking feminisation on the European scale. In other words, the requirements and expectations directed at teachers do not go hand in hand with economic and social gratification.

Yet another problem surfaces in the need for modernisation of practice provided for the candidates for the teaching profession at schools and other educational institutions. It appears that it is the most neglected area in the state of their professional preparation. It is still a universally acknowledged truth that the only source of knowledge about schools for the graduates of teacher-training institutions is their own experience from the time when they were pupils themselves.

Therefore, among the most urgent postulates related to teacher training, there are the following: extension of time framework for obligatory school practice, execution of the practice at different types and levels of schools, familiarisation with various types of educational institutions. This is meant to familiarise students with all aspects of educational reality. Purposeful selection of schools for the execution of on-the-job training is emphasised and the requirement for methodical cooperation between the school and the higher education institution is accentuated.

Also, the old practice of creating exemplary schools in which it would be possible to nourish and develop, present and propagate patterns of "proper pedagogical work" is postulated to return (Zawadowski, p. 3).

And ultimately, the area of academic research still remains noticeably neglected, including pedeutological research, despite of the fact, according to forceful 
prominence attached to it by the Bologna Declaration, that at the end of the day, it is research which is going to influence the level of attractiveness and competiveness of the European Space of Higher Education, which remains in close relation with the formation of the European Research Space, European Educational Space and European Space of Lifelong Learning.

\section{Expectations towards contemporary teachers - conditions of social expectations}

The profession of a teacher should be redefined through the prism of contemporary social and economic changes. Demands towards future teachers, in the field of higher education, should be unified and realised in a planned way. As far as education of future teachers is concerned, wide process of selfdevelopment and shaping appropriate educational models which are oriented towards subjective treatment of the student should be taken into account.

Many research reports reveal that comprehensive education of teachers does not guarantee a better relationship between students and teachers or afavourable atmosphere at school. The process of teachers' education does not end with higher education diploma. Usually, every teacher who wants to get a pay rise is obliged to start postgraduate education. The most frequent motivating factor to make this effort is external motivation in the form of a higher salary.

In Poland, differently than in 17 European countries (Germany, Estonia, Ireland, France, Italy, Cyprus, Luxemburg, Malta, Austria, Portugal, Romania, Slovenia, Slovakia, Sweden, Great Britain, Croatia and Turkey), there is no supporting system for novice teachers, who have to deal with various challenges at the initial stage of their careers. In this period, they need special support which would counteract the resignation from practicing a profession.

The consequences of the lack of formal teacher supporting system increase proportionally with the phenomenon of "bubbles of new in a sea of old" (Nowak, 1994). New initiatives, taken by young engaged teachers, face the objections of the "old" teaching staff. As a result, it leads to the absorption of "young" teachers by old structures in a particular school and it is connected with the phenomenon of professional burnout syndrome. Hence, the process of teacher training should head for the appreciation of the teaching profession among the society and pay special attention to the teacher's role in the process of shaping such values that would significantly influence the future of young generation and self-development of teachers.

That is the moment when the role of a teacher, who is responsible for training and the educational process of a young people appears. It can promote or hinder the identification with the responsible attitude of a young man. Why is it the teacher, who should decide about teenagers' responsible attitudes? The answer is relatively simple: responsibility is inscribed in the role of a teacher.

"In literature concerning education the following levels of responsibility appear: 
1. The notion of teaching profession ethics (A.M. de Tocharzewski) - a teacher is responsible to the society for the effects of the educational work.

2. Responsibility as a positive feature of personality (F. Zawadzki) - shaping responsibility in educational work, in the course of training.

3. Responsible acting as a pedagogical directive (J. Dewey, H. Muszyński, J. Legowicz, K. Tomaschevsky) - shaping a model of students' responsibility in the process of moral education." (Pilch, 2003)

Hence, there are no doubts, that despite the fact that the crucial role in shaping teenagers' identity is moving from adults to peers, it is the teacher who can still play an important role in the process of creating teenage values. Contemporarily, it does not mean that there are no doubts what this role should involve.

In addition, a well-known motive appears, " (...) to educate people in a way, that the overall success (e.g. defensive force or formation of the political system, or an efficient functioning of communication devices and technical devices in general) determines motivation and actions of individuals and their other needs lead towards a decline, or to educate people and create the social system in the way that inside the system and due to its institutions individuals would care of overall success and would find the maximum security of their substantial individual needs." (Kotarbiński, 1989, p. 24)

It is evident, that the second possibility is more important from the pedagogical point of view and it is about to shape responsibility, which results from subjective treatment of individuality in a young man. Taking into consideration the fact that the educative role is shifting from parents to institutions, i.e. teachers, educator who represents the institution; the observation, that the teacher's role in creating responsible individual is more and more substantial, seems to be correct. Teachers' responsibility "can be considered as a relation between teachers' action and effects, with particular attention to effects of this action. Then, the role is defined as a relation between a teacher's activity and occurrences which were caused by this activity." (Pilch, 2003)

In the process of teacher training, there is a great flexibility left in choosing topics from the field of psychology and pedagogy which are discussed during classes. Hence, it is the lecturer who decides on which competencies a future teacher should develop. Classes are often only theoretical and consequently treated as an additional requirement for obtaining a course credit to be able to work as a teacher in the future. Teachers to be should receive appropriate professional training, to feel responsible for the process of pupils' education.

The interactive nature of pupil-teacher relationship must be based on a mutual trust according to taking responsibility for their own actions. A responsible teacher, who realizes tasks in a responsible and conscious way, becomes an appropriate partner for a young individual who notices the point in taking responsibility for his/ her life. In the proposed changes in teacher training there are no criteria for the assessment of the acquired skills in the field of social 
competencies and teachers' self-development except for revealing the results of studies.

The process of teacher training should be more focused on providing teachers with the so-called "soft competencies". That strategy of work with pupil is included in progressive models of teaching (Bolton, 1979, p. 10, Brandes and Ginnis, 1994, pp. 10-17), in which the teacher motivates, awakens pupils' interest, indicates the benefits from learning, tries to reduce pupils' stress to a minimum, in contrast to traditional models which usually enhance pupils' anxiety and lead to school neurosis.

Progressive models of teaching assume that a process of training must relate to inner motivation. Teacher should not take control over a pupil from outside by means of punishment and awards, which are still very attractive to teachers. Future teacher should be trained to be able to create an inner will to learn in a pupil.

Due to the environmental approach to one's development (Brzezińska, 2000, p. 53), the source of behavioural changes is located inside the system. Hence, the change is generated from the centre. It does not exclude the impact of the environment on human psychical structure transformation. However, according to this approach, it lost a driving force to initiate the process of changes in comparison to the developmental approach.

An appropriate treatment of a pupil as well as an appropriate exchange of information between both parties of interaction - pupils and teachers, i.e. conveying and verifying knowledge, results in a significant increase of pupils' interest in learning and, therefore, a longer knowledge storage period, and the ability to apply this knowledge in practice.

The efforts connected with introducing changes into the field of education should be made on the basis of an appropriate school personnel training. The struggle for a proper educational system is a struggle for subjective and freedom-based treatment of both parties of interpersonal relationships at school. Perceiving the situation in schools as a common ground of solving pupils' and teachers' dilemmas and not as a place which generates problems, gives a chance to create a system based on understanding and cooperation.

Problems of the lack of democratic approach to education come from both teachers and pupils. A "school unit" should be considered through the prism of history and the system. Problems at one system level result from as well as constitute problems at another system level. The perception of conflicts and problems as an opportunity for increasing the training quality and the quality of mutual relationships, is the key to changing the perception of school as an unfavourable place.

In interpersonal relationships, every party should feel free to choose the direction of the relationship in order to feel the sense of engagement and causation. Realizing the fact that various factors, sometimes independent of a person, influence the overall success of the educational process, the paper is 
meant to focus on inter- and intrapersonal-dependent values of parties engaged in the relationships, i.e. pupils and teachers.

"One of the philosophers and pedagogues once said, that if we are about to give freedom to pupils, we should give freedom to teachers first." (Gordon, 2000, p. 326). A healthy relationship is based on the mutual care of the fulfilment of the individual's own and the partner's needs. Without an inner balance, it is difficult to talk about the possibility to care for other people. Hence, it is only the care of both parties of intergenerational interaction at school, which can create an opportunity for the creation of an atmosphere based on mutual understanding as well as respect for an individual.

"Teachers are obliged to realize pupils' needs, even though their own needs have not been fulfilled. Our theory of balanced interpersonal relationships which are strictly based on the rule of mutual needs fulfilment assumes that teachers' needs must be fulfilled. Otherwise, they would not be prone to try to fulfil students' needs." (Gordon, 2000, p. 326).

The most important step towards fulfilment of individual needs is to realize his/her needs. Treating obstacles, which appear during the training process, i.e. as far as it comes to teachers - at their workplace, as a chance to develop instead of treating them as obstacles impossible to overcome, enables teachers to face them in a creative way. Many of the following objective problems, which impede the realisation of teachers' individual needs, appear in school situations:

1. The fact that teachers also appear as subordinates often involves them in various conflicts and situations in which they cannot act due to their own visions. "The real world in the majority of schools is the world, where conflicts are solved by means of strength and power. In the majority of schools teachers are obliged to implement decisions and seldom are they able to participate in the process of making them." (Gordon, 2000, p. 327) The above-mentioned approach to teachers sets a general example of solving problems inside institutions.

2. Numbness and resistance to changes. Despite long-term discussions regarding the need for a change in the field of school rules, the majority of schools resemble, as it comes to in-class relationships, the situation from the previous years. Regardless of the need for a change, among teachers and headmasters the resistance can be observed.

3. Imposing homogenous values. Because of various reasons, which most commonly result from the fear of losing control, teachers and pupils are imposed to obey rules and norms without any possibility to participate in the process of creating them in many schools.

4. Pinning the blame to other people. In every school, there is a perfectly planned system of shifting the responsibility for failures from teachers to parents, from parents to the educational system, etc. Seldom, the school unit is able to reveal its weaknesses as a field to introduce changes. 
5. Inadequate salary in comparison to teachers' social role. According to the "Key Data on Teachers and School Leaders in Europe" survey, in the majority of countries, including Poland, the minimal basic remuneration of primary and lower secondary school staff before tax is lower than GDP per citizen.

\section{Conclusion}

Despite such an optimistic report as the Report on the State of Education 2012 TALIS "Outcomes matters" (Federowicz and Woźnicki, 2013), the situation of many school teachers, graduates or students who intend to be future teachers is still unsatisfying. The consequences of deficiency or indolence in the process of rational changes* implementation in broadly defined education are suffered by the last link of the educational chain, i.e. by pupils.

Changes, which are perceived by the authors of reforms as valuable, are interpreted by teachers as an external pressure, because of which they are obliged to report back and on which their professional development is dependent. According to a research focused on primary and lower secondary school teachers from the Greater Poland Province, in almost every conversation, inter alia, the motive of "test dictatorship" appeared.

Test results have become the tool of pressure exertion on teachers, the banner under which schools are promoted. Hence, teachers train pupils due to tests, parents collect copies of tests from previous years, pupils learn an imitative way of thinking. Therefore, the educational system in Poland, regardless of numerous changes introduced "from above", is still a system of traditional teaching and is focused on the effects, as the title of above-mentioned report indicates.

Unfortunately, the expected effects are statistical effects only directly related to the results of school achievement tests. Inside the whole system, unhappy pupils and dissatisfied teachers still exist. In consequence, pupils' education based on preparing them for tests limits the development of critical thinking, leads to shaping passive attitudes. Tests results and statistical analysis outcomes, as the above mentioned reports, are ravishing but still bare results.

Graduates enter life equipped with the ability to solve tests, which is an unnecessary skill in everyday life. Nowadays, an average student is not able to ask questions, analyse facts, draw conclusions or reinterpret the reality. The educational system changes do encourage, since in the nearest future there will be a lack of people willing to change the reality in a deliberate way.

\footnotetext{
*Obviously, we cannot say that there is a lack of changes in education system, since in the last 15 years Law on the Education System, i.e. the constitution of the system of education in Poland has changed approximately once per quarter! Successive ministers of education issued an average of nearly 2.5 regulation/decree every month.
} 


\section{References}

ANDRZEJAK, Z. and KUCHARSKA, C. Nauczyciel nowych czasów. ANDRZEJAK, Z., KACPRZAK, L. and PAJAK, K. (eds.). Polski system edukacji po reformie 1999 roku. Stan, perspektywy, zagrożenia. PoznańWarszawa: Wyd. Elipsa, 2005.

BOLTON, G. and TOWARDS, A. Theory of Drama in Education. London, 1979.

BRANDES, D. and GINNIS, P. A Guide to Student-Centred Learning. Hemel Hampstead, 1994.

BRZEZIŃSKA, A. Społeczna psychologia rozwoju. Warszawa, 2000.

Deklaracja Bolońska - Szkolnictwo Wyższe w Europie. Deklaracja Bolońska, $i$ co dalej. Poznań: UKA, 2004.

FEDEROWICZ, M., and WOŹNICKI, J. Liczq się efekty. Raport o stanie edukacji 2012. Warszawa, 2013.

FURMAŃSKA, M. 2005. Logos i Etos kształcenia uniwersyteckiego w gospodarce rynkowej. ANDRZEJAK, Z., KACPRZAK, L. and PAJAK, K. (eds.). Polski system edukacji po reformie 1999 roku. Stan, perspektywy, zagrożenia. Poznań-Warszawa: Wyd. Elipsa, 2005.

GORDON, T. Wychowanie bez porażek w szkole. Gdańsk, 2000.

KOTARBINSKI, T. Pisma etyczne. Wrocław, 1989.

NOWAK, A. Bable nowego w morzu starego: podwójna rzeczywistość okresu przemian spotecznych. Warszawa, 1996.

Organizacja systemu edukacji w Polsce 2008/09 [online]. Warszawa: Euridice. Available from:

http://eacea.ec.europa.eu/education/eurydice/documents/eurybase/eurybase_full_ reports/PL_PL.pdf.

PILCH, T. (ed.). Encyklopedia pedagogiczna XXI wieku. Tom III. Warszawa: Wydawnictwo Naukowe Żak, 2003.

Struktury systemów szkolnictwa wyższego w Europie 2006/2007. Proces Boloński: kierunki rozwoju w poszczególnych krajach. Warszawa: Euridice, 2008 .

Szkolnictwo wyższe w Europie 2009: postęp w realizacji Procesu Bolońskiego. Warszawa: Euridice, 2010.

Szkoty wyższe i ich finanse. Warszawa: GUS, 2007.

WALTOŚ, S. and ROZMUS, A. (eds.). Szkolnictwo wyższe w Polsce. Ustrój, prawo, organizacja. Rzeszów: Wyd. WSIiZ, 2009.

WIŁKOMIRSKA, A. Ocena ksztatcenia nauczycieli w Polsce. Warszawa: ISP, 2005.

Zapewnienie jakości $w$ kształceniu $i$ doskonaleniu zawodowym nauczycieli $w$ Europie. Warszawa: Euridice, 2007.

WŁOCH, S. W poszukiwaniu innowacyjnego modelu ksztatcenia nauczycieli. ANDRZEJAK, Z., KACPRZAK, L. and PAJAK, K. (eds.). Polski system 
edukacji po reformie 1999 roku. Stan, perspektywy, zagrożenia. PoznańWarszawa: Wyd. Elipsa, 2005.

Internet sources

BANASZAK, B. Proces Boloński oczami studentów. Available from:

http://www.forumakad.pl/archiwum/2009/10/40_proces_bolonski_oczami_stude ntow.html.

Kształcenie nauczycieli przez wyższe uczelnie. Komunikat. Ministerstwo Edukacji Narodowej. Available from:

http://riad.pk.edu.pl/ naszapol/archiwum/NR30/TEXT/9.htm.

Organizacja systemu edukacji w Polsce 2008/09. Warszawa: Euridice. Available from:

http://eacea.ec.europa.eu/education/eurydice/documents/eurybase/eurybase_full_ reports/PL_PL.pdf.

RĘKAWEK A. Wokót standardów ksztatcenia, cf: Instytut Spraw Publicznych Available from:

http://www.isp.org.pl/files/15184530420359963001118066595.pdf.

ZAWADOWSKI, W. Glos w sprawie ksztatcenia nauczycieli. Instytut Spraw Publicznych. Available from:

http://www.isp.org.pl/files/15184530420359963001118066595.pdf.

http://www.ibe.edu.pl/pl/o-instytucie/aktualnosci/293-pisa-2012-wyniki.

[viewed 23 June 2014].

http://eduentuzjasci.pl/badania/110-badanie/599-talis-miedzynarodowe-badanienauczania-i-uczenia-sie-2.html. [viewed 23 June 2014].

Polish legal acts cited in the publication

Ustawa z dnia 12 września 1990r. o szkolnictwie wyższym (The 12 September 1990 decree on higher education).

Ustawa z dnia 26 czerwca 1997r. o wyższych szkołach zawodowych (The 26 June 1997 decree on higher vocational schools).

Ustawa z 27 lipca 2005 r. Prawo o szkolnictwie wyższym (The 27 July 2005 Higher education law).

Ustawa z dnia 7 września 1991 r. o systemie edukacji (The 7 September 1991 decree on education system).

Rozporządzenie Ministra Edukacji narodowej z 12 sierpnia 1997 roku w sprawie zakładów kształcenia nauczycieli (The 12 August 1997 resolution of the Minister of National Education on teachers' training institutions).

Rozporządzenie Ministerstwa Edukacji Narodowej i Sportu z 23 lipca 2004 roku w sprawie rodzajów dyplomów i tytułów zawodowych oraz wzorów dyplomów wydawanych przez uczelnie (The 23 July 2004 resolution of the Minister of National Education and Sport on the types of diplomas and professional titles, as well as on designs of diplomas issued by higher education institutions). 
Rozporządzenie Ministra Edukacji Narodowej i Sportu z dnia 7 września 2004 r. w sprawie standardów kształcenia nauczycieli (The 7 September 2004 resolution of the Minister of National Education on standards of teachers' instruction).

Rozporządzenie Ministra Edukacji Narodowej z dnia 30 czerwca 2006 r. w sprawie standardów kształcenia nauczycieli w kolegiach nauczycielskich i nauczycielskich kolegiach języków obcych (The 30 June 2006 resolution of the Minister of National Education on teachers' training at Teachers' Training Colleges and Foreign Language Teachers' Training Colleges).

Ustawa z 26 stycznia 1982 r. Karta Nauczyciela (The 26 January 1982 Teacher's Charter).

Rozporządzenie Ministra Nauki i Szkolnictwa Wyższego z dnia 3 października 2006 r. w sprawie warunków i trybu przenoszenia osiągnięć studenta (The 3 October 2006 resolution of the Minister of Science and Higher Education on the conditions and methods of students' achievement transfer).

Rozporządzenie Ministra Nauki i Szkolnictwa Wyższego z dnia 19 grudnia 2008 r. w sprawie rodzajów tytułów zawodowych nadawanych absolwentom studiów i wzorów dyplomów oraz świadectw wydawanych przez uczelnie (The 19 December 2008 resolution of the Minister of Science and Higher Education on the types of professional titles issued to graduates and on designs of diplomas and certificates issued by higher education institutions). 